\title{
PENGARUH PENAMBAHAN ALAT PENCARI ARAH SINAR MATAHARI DAN LENSA CEMBUNG TERHADAP DAYA OUTPUT SOLAR CELL
}

\author{
Ahmad Yani \\ Jurusan Teknik Mesin Fakultas Teknik Universitas Trunajaya Bontang. \\ Jl.Taekwondo RT.9 No. 55 Telp./Fax. (0548) 3035920 Bontang-Kaltim 75311 \\ Email: yanibima@gmail.com
}

\begin{abstract}
Abstrak
Solar cell yang kita kenal saat ini masih memiliki beberapa kekurangan, salah satunya adalah daya yang dihasilkan kurang maksimal, oleh karena itu diperlukan sebuah alat tambahan yang dapat meningkatkan daya solar cell. Tujuan dari penelitian ini adalah untuk mengetahui efek dari penambahan arah pencari sinar matahari dan lensa cembung pada panel solar cell terhadap daya output yang dihasilakan. Metode penelitian yang digunakan adalah metode eksperimen dengan rancangan percobaan berskala kecil atau laboratorium. Hasil penelitian menunjukan adanya pengaruh penambahan alat pencari arah sinar matahari dan lensa cembung terhadap daya output solar cell. Daya tertinggi terjadi pada jam 14:00 dengan alat tambahan dikarenakan solar sell selalu mengikuti arah pencari sinar matahari serta lensa cembung dengan nilai daya output sebesar 0,251 watt, untuk daya terendah terjadi pada jam 07:00 dengan nilai daya output sebesar 0,203 watt. Sedangkan pada solar cell yang tidak dilengkapi alat pencari arah sinar matahari dan lensa cembung mendapatkan daya maksimal pada jam 12:00 dengan nilai daya output sebesar 0,226 watt. Sedangkan daya terendah terjadi pada jam 07:00 dengan nilai daya output sebesar 0, 00004 watt.
\end{abstract}

Kata kunci :, Pencari arah sinar matahari, lensa cembung, daya output, dan Solar cell.

\section{PENDAHULUAN}

Matahari merupakan sumber energi yang bersih dan ramah lingkungan. Energi ini sangat cocok digunakan pada negara tropis seperti di Indonesia, karena letak geografis Indonesia yang berada di atas garis katulistiwa maka Indonesia memiliki potensi energi surya yang sangat besar. Setiap hari, di Indonesia dapat diperoleh energi sebesar 4,8-6,0 kWh/m2 pada bidang horizontal yang tidak terlindung. Energi ini dapat dimanfaatkan secara langsung maupun segara tidak langsung. [1]

Secara langsung energi matahari dapat dimanfaatkan untuk meneringkan pakaian, hasil pertanian, maupun sebagai pemanas air. Pada pembangkit listrik tenaga matahari langsung, cahaya matahari difokuskan ke sebuah menara untuk memanaskan cairan didalamnya yang akan digunakan untuk memutarkan turbin.

Pemanfaatan energi listrik yang berasal dari matahari juga dapat dilakukan menggunakan efek photovoltaic, efek photovoltaic ini digunakan dalam sebuah solar cell yang terdiri dari susunan semiconductors untuk menghasilkan energi listrik. Namun sayangnya solar cell yang kita gunakan masih memiliki daya yang kecil dibandingkan dengan biaya pembelian yang relative mahal, apalagi jika solar cell tersebut menggunakan sudut pemasangan yang tetap. [3]

Untuk memaksimalkan unjuk kerja dari system solar cell maka diperlukan sebuah alat tambahan yang dapat membuat solar cell menghasilakan daya listrik yang maksimal. Penelitian ini dilakukan untuk mengetahui efek dari penambahan alat Pencari arah sinar matahari dan lensa cembung terhadap daya output solar cell yang dihasilakan. [8] 


\section{TINJAUAN PUSTAKA}

\section{Pengertian Solar cells (Photovoltaic)}

Menurut bahasa, kata Photovoltaic berasal dari bahasa Yunani photos yang berarti cahaya dan volta yang merupakan nama ahli fisika dari Italia yang menemukan tegangan listrik. Secara sederhana dapat diartikan sebagai listrik dari cahaya. Photovoltaic merupakan sebuah proses untuk mengubah energi cahaya menjadi energi listrik. Proses ini bisa dikatakan kebalikan dari penciptaan laser.

Solar cells atau panel surya adalah alat untuk mengkonversi tenaga matahari menjadi energi listrik. Photovoltaic adalah teknologi yang berfungsi untuk mengubah atau mengkonversi radiasi matahari menjadi energi listrik secara langsung. Efek photovoltaic pertama kali ditemukan oleh Henri Bacquerel pada tahun 1839, efek photovoltaic adalah sebuah fenomena dimana suatu sel photovoltaic dapat menyerap energi cahaya kemudian merubahnya menjadi energi listrik. Selain pada Solar cells, fenomena ini dapat pula kita amati disaat kita menjemur sebuah diode dan pada kedua kaki dari diode akan menghasilkan arus listrik.

\section{Prinsip kerja Solar cells (Photovoltaic)}

Energi solar atau radiasi cahaya terdiri dari biasan foton-foton yang memiliki tingkat energi yang berbeda-beda. Perbedaan tingkat energi dari foton yang menentukan panjang gelombang dari spectrum cahaya. Ketika foton mengenai suatu sel photovoltaic, maka foton tersebut dapat dibiaskan dan diserap kemudian diteruskaan menembus sel photovoltaic. Foton yang diserap oleh sel photovoltaic inilah yang akan memicu timbulnya energi listrik.

Pada siang hari modul surya/panel solar cell menerima cahaya matahari yang kemudian diubah menjadi listrik melalui proses photovoltaic. Energi listrik yang dihasilkan oleh modul surya dapat langsung disalurkan ke beban atau disimpan dalam baterai sebelum digunakan ke beban. Dan arus searah DC (direct current) yang dihasilkan dari modul surya yang telah tersimpan dalam baterai sebelum digunakan ke beban terlebih dahulu. Ilustrasi prinsip kerja solar cell sebagaimana ditunjukkan pada gambar 1 . [5]

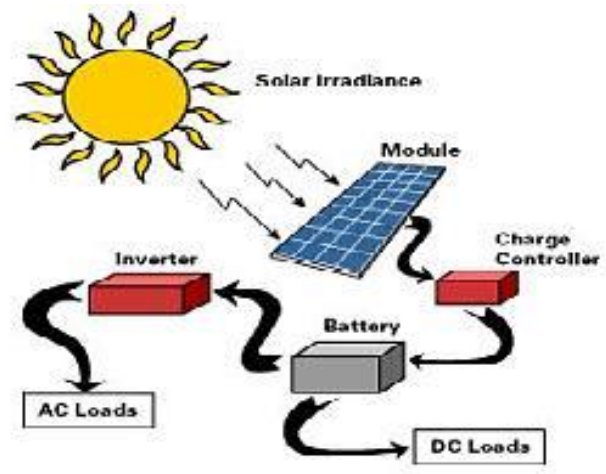

Gambar 1. Konsep kerja solar cell [5]

\section{Karakteristik Panel Fotovoltaik}

Sifat-sifat listrik dari modul surya biasanya diwakili oleh karakteristik arus tegangannya. Jika sebuah modul surya dihubung singkat $\left(\mathrm{V}_{\text {modul }}=0\right)$, maka arus hubung singkat $\left(\mathrm{I}_{\mathrm{sc}}\right)$ mengalir. Pada keadaan rangkaian terbuka $\left(\mathrm{I}_{\text {modul }}=0\right)$, maka tegangan modul disebut tegangan terbuka $\left(\mathrm{V}_{\text {oc }}\right)$.[4]

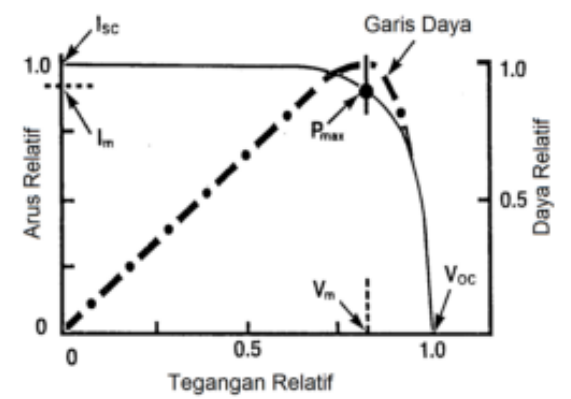

Gambar 2. Kurva Arus-Tegangan [4]

Daya yang dihasilkan modul surya, adalah sama dengan hasil kali arus dan tegangan yang dihasilkan oleh modul surya. Persamaan daya sebagaimana ditunjukkan pada persamaan 1. [5]

$$
P=V x I \text {. }
$$

Dengan :

$\mathrm{P}=$ Daya keluaran modul (Watt)

$\mathrm{V}=$ Tegangan kerja modul (Volt)

$\mathrm{I}=$ Arus kerja modul (Amperee) 


\section{METODOLOGI PENELITIAN}

Penelitian ini dilakukan di lingkungan Universitas Trunajaya Bontang pada Bulan Januari 2016 dan waktu pengambilan data dari jam 07.00 sampai 17.00 WITA.

\section{Variabel Penelitian}

Ada dua jenis variabel yang digunakan dalam penelitian ini yaitu variabel bebas dan variabel terikat.

1. Variabel bebas

Variabel bebas adalah variabel yang bebas ditentukan nilainya sebelum dilakukan penelitian. variabel bebas yang ditetapkan oleh peneliti adalah watu pengambilan data dari solar cell dengan tegangan kerja 5 volt 300 mili ampre yang akan diambil tiap satu jam.

2. Variable terikat

Variabel terikat adalah variabel yang nilainya sangat tergantung pada variabel bebas dan merupakan hasil dari penelitian variabel bebas yang diamati peneliti adalah daya output solar cell.

\section{Bahan dan Alat Penelitian}

Pada penelitian kali ini digunakan dua buah solar cell polycristaline dengan bentuk bulat yang memiliki ukuran diameter frame 70 milimeter dan panjang cell 50 milimeter dan lebar 48 milimeter dengan spesifikasi tegangan kerja 5 volt dan sebuah lensa cembung spesifikasi diameter 140 milimeter dengan fokus 100 milimeter serta sebuah motor DC (direct current).

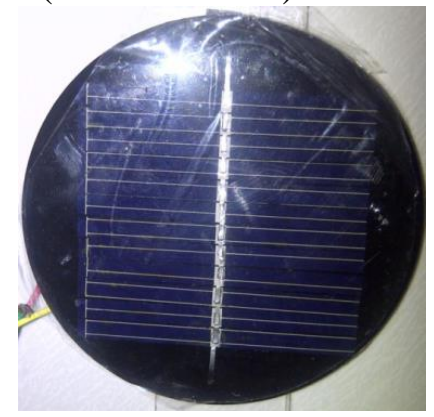

Gambar 3. Solar cell

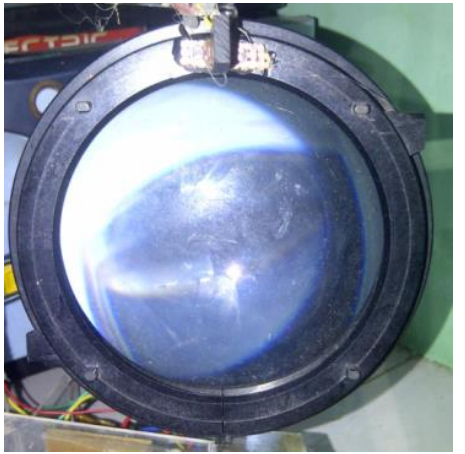

Gambar 4. Lensa cembung

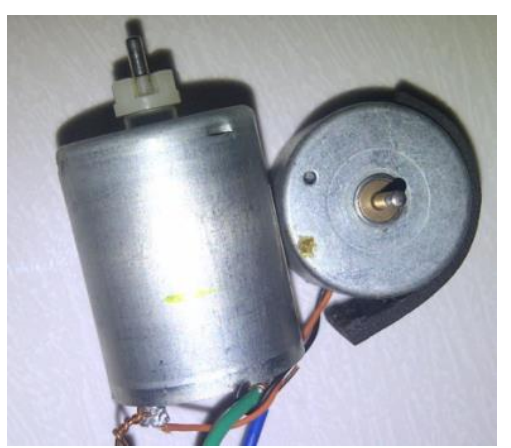

Gambar 5. Motor DC

Controller Pencari Arah Matahari. Controller tersebut berisikan komponen sebagai berikut: [6,8]

a. IC op-amp LM324 berfungsi sebagai komparator yang akan membandingkan input pada kaki A dan B, kika kaki A lebih atau sama dengan kaki B maka IC akan mengeluarkan arus suplay 5 volt pada kaki output.

b. LDR (Light Dependent Resistor) berfungsi sebagai sensor cahaya yang akan memiliki hambatan yang berbeda terhadap intensitas cahaya yang jatuh diatasnya.

c. Transistor berfungsi sebagai switch yang akan bekerja mengalirkan arus listrik dari emitter ke collector jika base mendapatkan ground.

d. Dioda berfungsi sebagai cek valve yang akan mengalirkan arus listrik hanya dari anoda ke katoda.

e. Kapasitor disini difungsikan sebagai penstabil tegangan listrik yang masuk ke dalam sistem agar mengurangi fluks.

f. Resistor berfungsi memberikan hambatan listrik yang akan masuk 
menuju ke LDR agar tegangannya berkurang.

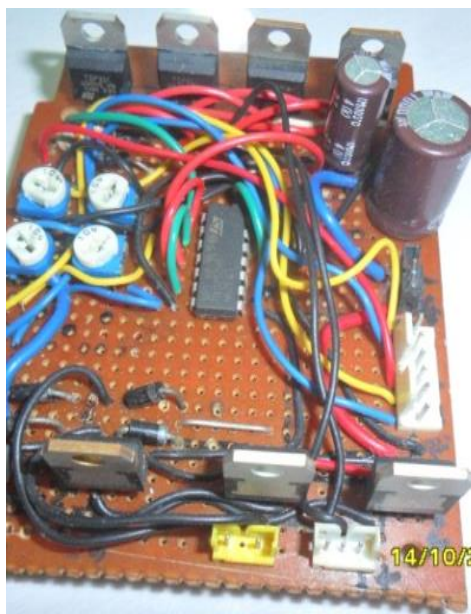

Gambar 6. Controller/ rangkaian electrical

\section{Alat Penelitian}

a. Volt Meter Digunakan untuk mengukur tegangan pada output solar cel maupun input controller.

b. Ampre meter yang digunakan yaitu merek sanwa. Yang berfungsi mengukur arus pada output solar cell jika diberi hambatan.

c. Ohm meter digunakan untuk mengukur resistan pada komponen resistor baik yang tetap, variable maupul LDR.

\section{Prosedur Penelitian}

Tahap persiapan.[8]

a. Membuat rangkaian electrical pada program Liveware. Rangkaian electrical seperti ditunjukkan pada gambar 7

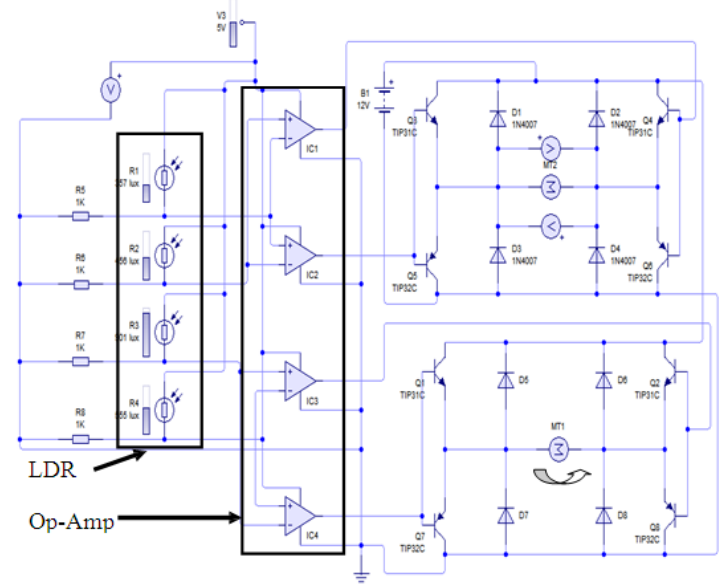

Gambar 7. Rancangan rangkaian elekrical b. Persiapan dan pemasangan seluruh alat ukur yang digunakan dalam pengujian, seperti: ampremeter, voltmeter dan alat pendukung lainnya.

c. Kalibrasi seluruh alat ukur.

Tahap pengujian [8]

a. Pasang solar sell dengan sudut $90^{0}$ terhadap permukaan tanah dan pasang solar cell yang telah dilengkapi oleh pencari arah cahaya matahari dan lensa cembung

b. Lakukan pengukuran tegangan dan arus output solar cell tiap jam mulai pukul 07:00 s/d pukul 17:00 Wita

c. Setelah data tegangan dan arus didapatkan maka kita dapat mengolah data mendapatkan nilai daya output yang dihasilakan, selanjutnya data daya tersebut dijadikan dalam bentuk grafik.

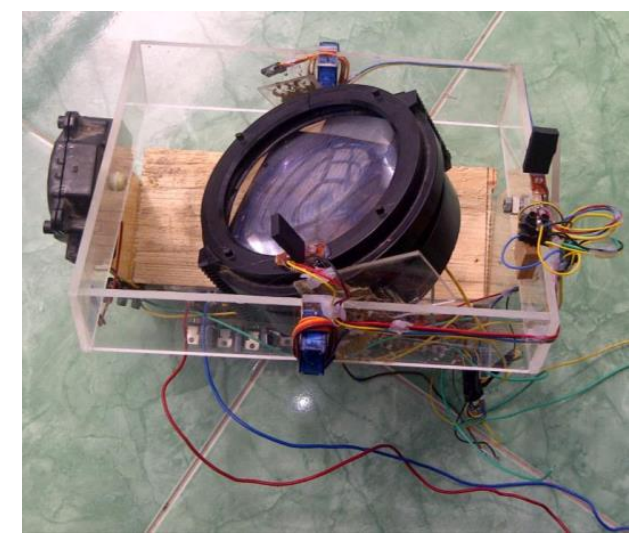

Gambar 8. Prototipe Solar cell yang diteliti

\section{HASIL DAN PEMBAHASAN}

Dari hasil pengukuran tegangan dan arus pada output solar cell tiap jam mulai pukul 07:00 s/d pukul 17:00 Wita. Setelah data tegangan dan arus didapatkan maka kita dapat mengolahnya dan mendapatkan hasil berupa daya dari output solar cell. Pada penelitian ini teknik analisa data menggunakan teknik deskriptif berdasarkan hasil penelitian yang dilakukan. Data yang diperoleh dari hasil penelitian kemudian dianalisis menggunakan rumus terapan, Selanjutnya data akan disajikan dalam bentuk grafik dengan bantuan Microsoft Office Excel hasil penelitian yang dilakukan. 
Hasil pengolahan data penelitian yang dilakukan dengan cara menggunakan persamaan untuk menghitung daya output solar cell adalah $P=$ $V . I$. Data keseluruhan hasil pengolahan pada pengujian panel solar cell seperti ditunjukkan pada tabel 1.

Tabel 1. Data hasil pengolahan pada pengujian daya output solar cell

\begin{tabular}{|c|c|c|}
\hline $\begin{array}{c}\text { Waktu } \\
\text { pengambilan } \\
\text { data }\end{array}$ & $\begin{array}{l}\text { Tanpa alat } \\
\text { tambahan }\end{array}$ & $\begin{array}{l}\text { Dengan alat } \\
\text { tambahan }\end{array}$ \\
\hline $07: 00$ & 0.000 & 0.203 \\
\hline $08: 00$ & 0.018 & 0.233 \\
\hline $09: 00$ & 0.125 & 0.240 \\
\hline $10: 00$ & 0.204 & 0.248 \\
\hline $11: 00$ & 0.213 & 0.245 \\
\hline $12: 00$ & 0.226 & 0.246 \\
\hline $13: 00$ & 0.222 & 0.248 \\
\hline $14: 00$ & 0.199 & 0.251 \\
\hline $15: 00$ & 0.197 & 0.244 \\
\hline $16: 00$ & 0.139 & 0.243 \\
\hline $17: 00$ & 0.032 & 0.232 \\
\hline
\end{tabular}

Data dari tabel 1 di atas merupakan data hasil pengolahan daya output solar cell, data tersebut kemudian dijadikan grafik daya output solar cell sebagaimana ditunjukkan pada gambar 9.

\section{Grafik Daya VS Waktu}

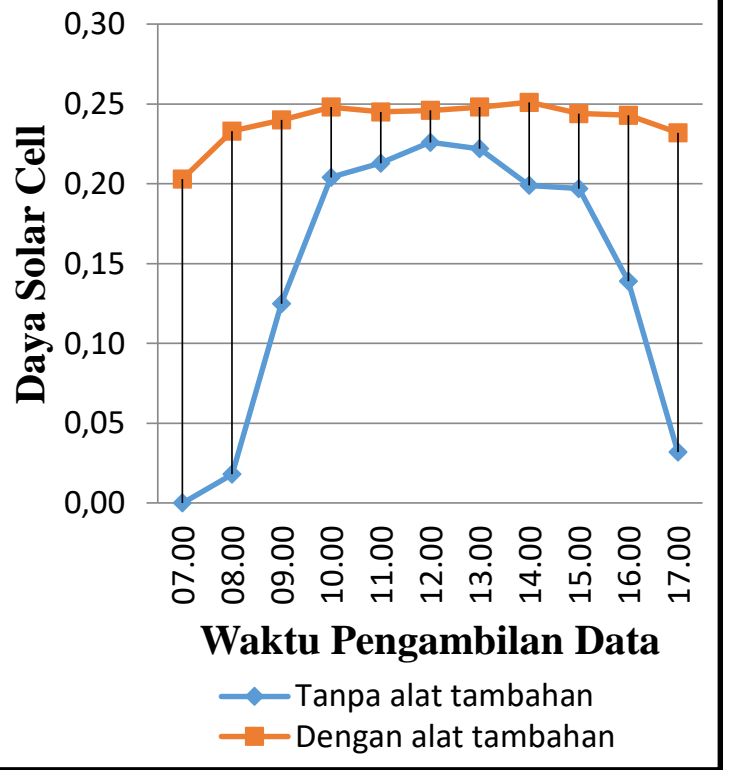

Gambar 9. Grafik daya output solar cell
Dari gambar 9 dilihat secara keseluruhan pada penelitian ini terjadi penambahan daya solar cell yaitu mulai pukul 07.00 hingga 17.00 dikarenakan fungsi dari pencari arah sinar matahari yang akan membuat cahaya jatuh tegak lurus terhadap lensa cembung yang akan meningkatkan intensitas cahaya yang diterima oleh solar cell.

Daya tertinggi terjadi pada jam 14:00 dengan alat tambahan dikarenakan solar sell selalu mengikuti arah pencari sinar matahari serta lensa cembung yang akan meningkatkan intensitas cahaya yang diterima oleh solar cell tersebut dengan nilai daya output sebesar 0,251 watt, untuk daya terendah dengan alat tambahan terjadi pada jam 07:00 dengan nilai daya output sebesar 0,203 watt.

Sedangkan pada solar cell yang tidak dilengkapi alat pencari arah sinar matahari dan lensa cembung, yang diletakan secara statis pada sudut tegak lurus terhadap permukaan tanah mendapatkan daya maksimal pada jam 12:00 dengan nilai daya output sebesar 0,226 watt. Sedangkan daya terendah terjadi pada solar cell yang tidak ada alat tambahan pada jam 07:00 dengan nilai daya output sebesar 0,00004 watt.

\section{KESIMPULAN}

Alat pencari arah sinar matahari yang dilengkapi dengan lensa cembung berpengaruh besar terhadap daya output yang dihasilkan solar cell.

Daya tertinggi terjadi pada jam 14:00 dengan alat tambahan dikarenakan solar sell selalu mengikuti arah pencari sinar matahari serta lensa cembung dengan nilai daya output sebesar 0,251 watt, untuk daya terendah terjadi pada jam 07:00 dengan nilai daya output sebesar 0,203 watt.

Sedangkan pada solar cell yang tidak dilengkapi alat pencari arah sinar matahari dan lensa cembung mendapatkan daya maksimal pada jam 12:00 dengan nilai daya output sebesar 0,226 watt. Sedangkan daya terendah terjadi pada jam 07:00 dengan nilai daya output sebesar 0,00004 watt. 


\section{DAFTAR PUSTAKA}

[1]Anonim $2005 \quad$ Photovoltaic Fundamentals,

[2]Budhi Priyanto, April 2013, Peningkatan Daya Keluaran Sel Surya Dengan Penambahan Intensitas Berkas Cahaya Matahari, Jurnal Neutrino Vol.5, No. 2, Teknik Elektro Fakultas Teknik Universitas Muhammadiyah Malang

[3]Budi Yuwono, Februari 2005, Optimalisasi Panel Sel Surya Dengan Menggunakan Sistem Pelacak Berbasis Mikrokontroler At89c51, Universitas Sebelas Maret, Surakarta

[4]Sumbung, F.H. dan Letsoin, Y, 2012, analisa dan estimasi radiasi konstan energi matahari melalui Variasi sudut panel fotovoltaik shs 50 wp Jurnal Ilmiah Mustek Anim

[5]khsan, 2013, Peningkatan Suhu Modul Dan Daya Keluaran Panel Surya Dengan Menggunakan Reflektor, Jurnal ilmiah Dosen pada Jurusan Fisika Fakultas Sains dan Teknologi UIN Alauddin Makassar.

[6]Muhammad. R, 2003, Elektronika Daya, Jilid 1, Prentice Hall Inc., New Jersey

[7]Mukund R. P, 2000, Wind And Solar Power Sistem, S Merchant Marine Academy Kings, New York

[8]Sodiqin. A dan Yani. A. 2016, Analisa charging time sistem solar cell menggunakan pencari arah sinar matahari yang dilengkapi dengan pemfokus cahaya. Jurnal turbo program studi Teknik Mesin Universitas Muhammadyah Metro Lampung. Volume 5 No. 1 Juni 2016 